Digital Gaming and the Advertising Landscape 



\section{Digital Gaming and the Advertising Landscape}

Teresa de la Hera 
The publication of this book was made possible by the research project Persuasive gaming. From theory-based design to validation and back, funded by the Netherlands Organisation for Scientific Research (NWO; 2013-2018; project number 314-99-106).

Cover illustration: ( Miguel Méndez

Cover design: Coördesign, Leiden

Lay out: Crius Group, Hulshout

$\begin{array}{ll}\text { ISBN } & 9789462987159 \\ \text { e-ISBN } & 9789048538676 \\ \text { DOI } & 10.5117 / 9789462987159 \\ \text { NUR } & 670\end{array}$

(C) T. de la Hera / Amsterdam University Press B.V., Amsterdam 2019

All rights reserved. Without limiting the rights under copyright reserved above, no part of this book may be reproduced, stored in or introduced into a retrieval system, or transmitted, in any form or by any means (electronic, mechanical, photocopying, recording or otherwise) without the written permission of both the copyright owner and the author of the book.

Every effort has been made to obtain permission to use all copyrighted illustrations reproduced in this book. Nonetheless, whosoever believes to have rights to this material is advised to contact the publisher. 
To my son Jordi and my grandparents Celita and Cándido, because pursuing my dreams makes more sense thanks to three of them. 
